Sur le désir de se jeter à l'eau. Quignard, P. e Fenoglio, I. Paris: Presses Sorbonne Nouvelle, 2011.

\title{
Verónica Galíndez-Jorge
}

Há anos conhecemos obras dedicadas aos manuscritos de escritores. Dos cadernos manuscritos publicados sob a forma de facsímiles com transcrições, às ediçõos fac-similares de rascunhos; da publicação da fábrica de Francis Ponge, aos estados não acabados de edições de obras completas. O público, seja ele universitário ou não especializado, terá praticamente visto de tudo. Ora, foi necessário esperar esta última empreitada para que a literatura e a crítica testemunhassem um diálogo inédito, do qual nos foram legados apenas vestígios, certamente, mas, mais importante, reflexões.

Por um lado, temos o escritor, para quem a empreitada genética será objeto de análise antes de tornar-se algo próprio. Do outro, o investigador, que procura a gênese in vivo e que se verá dividido entre a construção da distância crítica e a proximidade do corpus que lhe é confiado diretamente.

Sur le désir nos apresenta a reprodução dos manuscritos de trabalho, com anotações e desenhos que compõem o dossiê genético de Boutès, de Pascal Quignard, publicado em 2008 pela editora Galilée e acompanhado de textos - as categorias narrativas não são úteis para descrevê-los -, dois que pertencem ao escritor e três à crítica e diretora de pesquisas do ITEM (Instituto de Textos e Manuscritos Modernos), Irène Fenoglio. Esses textos são testemunho da amizade que se construiu entre os dois, mas também de um pacto tácito de generosidade. O leitor confirmará a generosidade do escritor para com a crítica, mas também desta para com o escritor e dos dois, tornados autores deste livro, para com o público. De modo algum trata-se aqui de demonstrar um percurso de criação, como poderia dar ler a reprodução dos manuscritos, mas de tornar público um processo, uma aprendizagem, o desafio que se coloca às duas partes implicadas. A empreitada deste livro poderia ser situada muito mais do lado da criação de um novo tipo de corpus que do lado da constituição de um processo que se daria a ler e analisar.

Os dois, Quignard e Fenoglio, se lançam nos manuscritos, assim como faz Boutès, para efetivamente ouvir o canto das sereias, para a escuta recíproca. Os textos descortinam o contexto deste pro- 
jeto, as condições nas quais os manuscritos foram arquivados para serem posteriormente transmitidos ao investigador, que se interroga sobre como lê-los, como abordá-los.

Não se trata, como sugerido em outro lugar, de um dossiê escapado das chamas - Quignard costuma queimar seus manuscritos, ato que já foi filmado uma vez - mas da formalização de uma troca de natureza rara em nossos tempos: a da partilha. "Normalmente destruo tudo para que o quarto fique vazio. Para que a casa fique fazia. E também para que a vida fique vazia.

Aceitei. Irène Fenoglio ensinara-me tanto - desenganara-me tanto - sobre o meu próprio trabalho", afirma Quignard.

O escritor não se contenta em conservar seus traços para que outro avalie seu trabalho, ou sua eventual genialidade, mas decide lançar-se em um diálogo com a pesquisadora. Desse processo repleto de questionamentos, surge o projeto editorial que contempla a publicação dos manuscritos. Esse primeiro projeto não será publicado.

Por sua vez, a pesquisadora tenta compreender as razóes que levam-na a querer trabalhar sobre manuscritos tão contemporâneos, ultracontemporâneos: "[...] sempre pareceu-me que compreender o processo de criação pela escrita se beneficiaria de um olhar que fosse orientado para o que se escreve hoje, no tempo de um atual questionamento sobre a escrita". E esse objetivo é trabalhado sob forma de apresentação da escrita de Pascal Quignard, das pistas que permitem que o leitor leia os manuscritos publicados à sua maneira. Assim, os textos de Fenoglio apresentam as diferentes materialidades do conjunto genético: desenhos, fotos impressas, folios impressos a partir do uso de editor de texto e anotações manuscritas, papeletas manuscritas, para descrever um gesto de escrita, assim como suas "quedas" e questôes relativas à própria possibilidade de leitura de manuscritos. "Abrir o manuscrito permite passar o limiar, introduzir-se atrás da tela que o escritor constrói para si mesmo para, atrás dela, retirar-se. É crer na possibilidade de introduzir-se. De fato, permanecemos sempre sobre o limiar para passar ao ato do nosso próprio desejo".

Essas mesmas "quedas" serão objeto de escritos inéditos de autoria de Quignard e que formalizam a atividade de escrita tal como parece vivê-la: "Rupturas de oralidade, é o que são os livros".

Ainda que a pesquisadora nos chame a atenção: "Um manuscrito não se abre". Ainda que previna que o leitor se perderá, ele 
reencontrará, neste diálogo único e original, a essência de Boutès, o "único herói da antiguidade que terá tido a audácia de mergulhar no mar para juntar-se às sereias".

Trata-se, sem dúvida, de uma obra que acabará questionando os criadores e os pesquisadores, dado que será necessário incorporar definitivamente a materialidade dos manuscritos como evidência de diálogo à toda reflexão sobre a criação. Se por acaso a crítica vê-se incapaz de reconstituir um eventual interlocutor, pelo menos emergirá o diálogo que o ato em si, aquele de guardar vestígios, estabelece com a escrita como ato, como política, como partilha.

Verónica Galíndez-Jorge é professora de literatura francesa na área de Estudos Linguísticos, Literários e Tradutológicos em Francês do Departamento de Letras Modernas da USP. É autora de Fogos de artificio. Flaubert e a escritura. Traduziu, em colaboração com Roberto Zular, a coletânea de poemas franceses Dois ao cubo. Alguma poesia francesa contemporânea. Atualmente dirige a coleção Ecritures du XXIe siècle com Irène Fenoglio, dedicada a mapear e analisar a produção literária contemporânea. E-mail: <vegarj@usp.br>. 